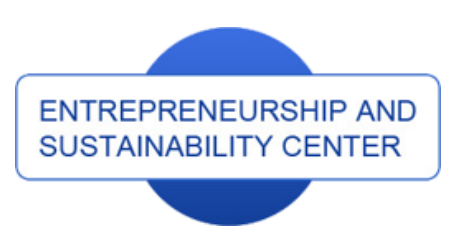

Publisher

\section{enterprise europe network}

Business Support on Your Doorstep
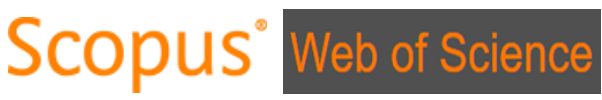

http://jssidoi.org/esc/home

1. Clarivate

Analytics

\title{
STRATEGIES OF INTERACTION WITH A CONSUMER WITHIN THE MARKETING PRODUCT POLICY
}

\author{
Oleksandra Stoian', Tetiana Polozova ${ }^{2}$, Evgen Didenko ${ }^{3}$, Oleksandra Storozhenko ${ }^{4}$, Olena Moskvichova ${ }^{5}$ \\ ${ }^{1 *}$ Petro Mohyla Black Sea National University, 68 Desantnykiv St, Mykolaiv, Mykolaivs'ka oblast 54000, Ukraine \\ ${ }^{2,3,4}$ Kharkov National University of Radio Electronics, Nauky Ave, 14, Kharkiv, Kharkivs'ka oblast 61000, Ukraine \\ ${ }^{5}$ Vinnytsia Financial and Economic University, Vinnytsia, Soborna str. 1121050, Ukraine \\ E-mail: ${ }^{1^{*}} \underline{\text { koaduep@gmail.com }}$
}

Received 22 August 2018; accepted 11 December 2018; published 30 December 2018

\begin{abstract}
A matrix of strategies for interaction with a consumer in the Internet is developed based on the use of two-vector coordinate system: the degree of consumer readiness to purchase and the communication environment. The means of promotion has been analyzed in accordance with the strategy of interaction with the consumer in the Internet. The KPI system for the communication activity of the enterprise in the Internet was proposed on the basis of crowd-technologies. The built matrix of areas of correction of the communication policy allows the company to determine the further direction of correction of communications for each level of communication influence.
\end{abstract}

Keywords: marketing product policy; strategy; communication policy; consumer; crowd-technologies

Reference to this paper should be made as follows: Stoian, O.; Polozova, T.; Didenko, E.; Storozhenko, O.; Moskvichova, O. 2018. Strategies of interaction with a consumer within the marketing product policy, Entrepreneurship and Sustainability Issues 6(2): 1018-1027. http://doi.org/10.9770/jesi.2018.6.2(36)

JEL Classification: M5, Q2 


\section{Introduction}

The marketing activity in the information society acquires new features of functioning both from the enterprise's side and from the consumer's side. The behaviour of consumers under the influence of Internet technologies is changing, which requires a rethinking of traditional processes of marketing activity of the enterprise.

In their papers, researchers (Wang, M., \& Qu, H. 2017) emphasize the significant role of information technology in economic relations of market players, which requires new approaches to marketing activities of enterprises. Information technology greatly affects the functioning of each subsystem of marketing, creating new opportunities and threats. In this context, scientists (Homburg, C., Jozić, D., \& Kuehnl, C. 2017) proposed an information marketing concept. Information marketing concept is a marketing activity of an enterprise that partially or fully operates on the Internet and uses marketing-specific strategies and business methods for the hypermedia environment to enhance its competitiveness (Markos, E., Labrecque, L. I., \& Milne, G. R. 2018). The development of information technology allows you to use individual marketing for the broad mass, satisfying the needs of each client, while covering a large number of orders. In this situation, the building of a system of the long-term marketing interaction of the company with its customers and other market players is becoming increasingly important in order to satisfy all parties in the process of economic interaction.

However, not only the manufacturer has access to information in the information society, but also consumers have the opportunity to get information about manufacturers, attractive offers on the market and the specifics of the process of buying and selling goods. In addition, the consumer not only receives this information, it also distributes it over the Internet and exchanges experience with other consumers and provides advices, using other technologies, and therefore influences further consumer behaviour of other participants.

In the process of this interaction, consumers began to unite into communities and virtual communities (Cole, S. J. 2017). Being in such communities, users actively interact with each other and affect consumer behaviour. In such a situation, enterprises can interact not only with individual consumers, but also with whole groups of consumers, who, unlike the mass market, actively influence each other.

\section{Methods}

In the process of forming a strategy of interaction with the consumer in the Internet, a qualitative assessment of the communication environment based on the analysis of the information environment that was carried out earlier is required. In order to assess the communication environment, it is necessary to analyze whether it is favorable or unfavorable for the specified manufacturer. The tool recommended to use in this case is content analysis.

The content analysis process involves the following steps:

1. Determination of the totality of the studied sources. Determination of the type of information source (press, Internet, radio broadcasts, etc.). Determination of the type of message (articles, recommendations on the site, publications in social networks, etc.). Determination of the communication side (the consumer who distributes the communication or the representatives of the companies). Determination of message spreading time (month, quarter, year) (Jacobsen, L. F., Tudoran, A. A., \& Lähteenmäki, L. 2017).

2. Formation of a sample of totality of messages for analysis by parameters determined in the first stage.

3. Selection of units of analysis. The content units include: concepts expressed in separate terms; themes expressed in paragraphs, parts of texts, articles, publications, etc.; brand names etc.; events, facts, etc.; the meaning of appeals to the potential recipient.

4. Determination of measurement indicators, which include: frequency, direction and intensity. The researcher can measure from one to three characteristics (Lou, L., \& Koh, J. 2017).

5. Procedure for encoding information according to the given parameters. 
6. Determination of the results of the content analysis.

Using the matrix developed by the author, we define the strategy of interaction with consumers in the Internet environment (Table 1).

Table 1. The matrix of strategies for interaction with the consumer on the Internet

\begin{tabular}{|c|c|c|c|}
\hline \multirow{4}{*}{$\begin{array}{l}\text { Degree of } \\
\text { readiness of } \\
\text { the consumer } \\
\text { to purchase }\end{array}$} & & \multicolumn{2}{|c|}{ Communication environment } \\
\hline & & Favourable & Inappropriate \\
\hline & High & $\begin{array}{l}\text { Strategy of development of relations- } \\
\text { sales (consumers ready to buy) }\end{array}$ & $\begin{array}{l}\text { Consumer return strategy (Potential } \\
\text { consumers } \\
\text { of competitors) }\end{array}$ \\
\hline & Low & $\begin{array}{l}\text { Consumer development strategy - } \\
\text { actualiazation of the need } \\
\text { (Potential consumers) }\end{array}$ & $\begin{array}{l}\text { Potential development strategy } \\
\text { (Problematic consumers) }\end{array}$ \\
\hline
\end{tabular}

The ready to buy consumers in the matrix proposed are the most promising consumers who are ready to buy, and who need direct targeted communication, aimed at selling the product. In this case, it is advisable to apply a strategy for development relations with the consumer. The implementation of this strategy is possible due to the use of advertising mechanism - targeting.

The next strategy in the matrix is the return strategy. This strategy involves work with potential competitors. These are potential customers who are ready to buy, but do not consider the company as a supplier of the product. This may be due to a lack of information about the supplier or a negative attitude to it. That is, the communication environment is unfavourable to promote the brand (negative feedback, strong competitor's positions in the consumer's perception, poor brand awareness). In this case, it is recommended to use a strategy of returning consumers through the spread of communication, emphasizing the benefits of the product relative to competitors, or the disadvantages of competitors. The work with these consumers involves improvement of the context, spreading the desired information in the company's communications environment and interested consumers.

\section{Results and discussions}

Internet technologies provide the opportunity to switch from mass marketing to individual. In an increasingly competitive climate, manufacturers aim at customization by creating individual consumer value of goods, adapting the characteristics of the product to the specific needs of the customer, the convenience of the process of buying. Moreover, the role of service is growing, which in some cases becomes more important than the product itself. Therefore, companies should be prepared to provide an individual approach to each customer.

Flexibility of business processes in the Internet allows faster success for enterprises in an interactive environment. Modern marketing activities in the development of Internet technologies are characterized by the following features: on the one hand, there is an economic globalization that applies to all economic entities and their interaction, that is, enterprises use the strategy of mass global marketing. On the other hand, there is a tendency of individualization/marketing localization, which is related to the need for more complete satisfaction of the needs of customers in the conditions of global severe competition from mass to segment/niche marketing (Hilorme, T., Chorna M., Karpenko L., Milyavskiy M. \& Drobyazko S. 2018).

That is, marketing activity in the conditions of the information society is formed on the basis of an individual approach to the consumer, in contrast to mass marketing in an industrial society. At the same time, the company does not operate on regional markets, as before, but enter the global market due to the use of Internet technologies. 
The International Journal

ENTREPRENEURSHIP AND SUSTAINABILITY ISSUES

ISSN 2345-0282 (online) http://jssidoi.org/jesi/

2018 Volume 6 Number 2 (December)

http://doi.org/10.9770/jesi.2018.6.2(36)

The Quadrant "potential consumers" defines consumers who are in a favourable informational environment, but for which the goods are latent need, that is, they are not yet ready to buy. The consumer development strategy implies an active spreading through the context of the communication aimed at actualization of the need at the consumer.

The last quadrant of the matrix is "problematic consumers". For these consumers, you need to work both on the information environment in which they are located, and on the actualiazation of need in the product. For this purpose it is expedient to use the strategy of potential development of consumers. It involves active work at both levels of communication impact, context level aimed at creation of the need in the product, disclosure of new opportunities for the use of the product, the advertising layer of communication aimed at emphasizing the advantages of the product compared with competitors.

In order to implement each of the proposed strategies, the enterprise may use appropriate means of promotion at each level of communication impact (Table 2).

Table 2. Means of promotion in accordance with the strategy of interaction with the consumer on the Internet

\begin{tabular}{|c|c|c|}
\hline Type of strategy & $\begin{array}{c}\text { Information level of communication } \\
\text { influence }\end{array}$ & $\begin{array}{c}\text { Product level of communication } \\
\text { influence }\end{array}$ \\
\hline $\begin{array}{l}\text { Strategy of development of } \\
\text { relations with the consumer }\end{array}$ & $\begin{array}{l}\text { Incite the agiotage around the } \\
\text { brand, support the level of anxiety } \\
\text { of consumers }\end{array}$ & $\begin{array}{l}\text { Active targeting and retargeting } \\
\text { targeted users in social networks } \\
\text { and contextual advertising. } \\
\text { Proposals for sales promotion } \\
\text { (discounts, promotions, quantity } \\
\text { limited, etc.) }\end{array}$ \\
\hline $\begin{array}{l}\text { Consumer } \\
\text { strategy }\end{array}$ & $\begin{array}{l}\text { Create demand for a product } \\
\text { category. Actualize the latent need } \\
\text { for goods (feedback on the benefits } \\
\text { of using the product) Emphasizing } \\
\text { the importance of the product } \\
\text { category, methods of use }\end{array}$ & $\begin{array}{l}\text { The advertising is focused on the } \\
\text { benefits of using the product. }\end{array}$ \\
\hline Consumer return strategy & $\begin{array}{l}\text { Change the importance of the } \\
\text { attributes on which the competitor is } \\
\text { more attractive } \\
\text { Weaken competitors by weakening } \\
\text { the strengths of the brand- } \\
\text { competitor }\end{array}$ & $\begin{array}{l}\text { Strategy of differentiation of the } \\
\text { brand, emphasis on the strengths } \\
\text { of the product. Emphasizing the } \\
\text { advantages and uniqueness of the } \\
\text { brand. Creation of additional } \\
\text { benefits for the consumer. } \\
\text { Increase customer after-sales } \\
\text { service }\end{array}$ \\
\hline $\begin{array}{l}\text { Strategy of potential consumer } \\
\text { development }\end{array}$ & $\begin{array}{l}\text { Creation a need for product, } \\
\text { opening new opportunities for } \\
\text { product use }\end{array}$ & $\begin{array}{l}\text { Emphasizing the advantages of } \\
\text { the product compared with } \\
\text { competitors, and creation of the } \\
\text { desired image of the company }\end{array}$ \\
\hline
\end{tabular}

So, having defined the strategy of interaction with the consumer in the Internet environment, the enterprise has the basis for development of a communication strategy. That is, the direction of the strategy of interaction with the consumer in the Internet is the basis for the further communication strategy.

The next block is the development of a communication strategy for the enterprise in the Internet environment and in general throughout the information space. In accordance with the chosen communication strategy, an optimal set of marketing communications is formed. Since we are talking about communication in the Internet 
environment, it is advisable to use such Internet communications as contextual and banner advertising, promotion in network communities and in forums for the discussion of products and services. To implement a particular strategy, an enterprise can use such tools as generation of content in the network, management of network communities dedicated to the brand, targeting and retargeting.

The targeting and retargeting mechanisms are very effective tools in the implementation process of crowdtechnologies in marketing communications. They provide the opportunity to personalize communications, target the targeted advertisement at a prospective consumer, whose psychographic or behavioural profile indicates the readiness of the consumer to make a purchase (Ponsford, R., et al. 2017). So, the mechanisms of targeting and retargeting considered give the possibility to implement selected strategies of communication policy and strategies of consumer behaviour management.

In order to assess the implementation of the communication strategy, it is recommended to analyze the key indicators of the effectiveness of communications, that is, to analyze the so-called key performance indicators (KPIs). KPIs are indicators of enterprise activity that help organizations achieve strategic and tactical (operational) goals. The use of key performance indicators enables organizations to assess their status and help assess the strategy implementation (Hilorme, T., Nazarenko Inna, Okulicz-Kozaryn, W., Getman, O. \& Drobyazko, S. 2018).

To develop our own KPI system, let's take as a basis for the study of an international organization in the field of content marketing Content Marketing Institute. (Oghazi, P., Karlsson, S., Hellström, D., \& Hjort, K. 2018) proposed to distinguish key metrics for analyzing the information environment for four content functions: perception, spreading or exchange of information, conversion and sale. The following KPI system of the communication activity of the enterprise in the Internet on the basis of crowd-technologies is proposed (Table 3 ).

Table 3. KPI system for determination of the effectiveness of the crowdmarketing

\begin{tabular}{|c|c|}
\hline Groups composed based on the content functions & Examples of indicators \\
\hline Return of investment (ROI) & $\begin{array}{l}\text { Proceeds from sale; } \\
\text { Selling cost; } \\
\text { Income (from one follovers, a lead, a buyer); } \\
\text { The share of regular customers (in social networks } \\
\text { compared to other channels). }\end{array}$ \\
\hline $\begin{array}{l}\text { Efficiency indicator for network information } \\
\text { exchange }\end{array}$ & $\begin{array}{l}\text { Number of links to messages; } \\
\text { Number of reposts; } \\
\text { Comments (quantity/quality); } \\
\text { Likes and ratings; } \\
\text { Reviews (quantity); } \\
\text { Participants and active members. } \\
\end{array}$ \\
\hline $\begin{array}{l}\text { Indicator of the efficiency of perception of network } \\
\text { information }\end{array}$ & $\begin{array}{l}\text { Number of pageviews (post); } \\
\text { Viewing time; } \\
\text { Number of downloads. }\end{array}$ \\
\hline Conversion Rate & $\begin{array}{l}\text { Conversions (mail subscription, download, } \\
\text { installation of widgets and tools, etc.); } \\
\text { Registered users; } \\
\text { Number of leads (day, week, month); } \\
\text { The cost of the lead. }\end{array}$ \\
\hline
\end{tabular}

The indicators used in the given KPI system may be aggregated from the enterprise's internal reporting, in particular from data counters, Internet community administration pages, and sales data. The first three groups of indicators are mostly technical, which complicates their unambiguous efficiency assessment. In general, thanks to 
the KPI system, it is possible to assess the intensity of company promotion in social media by means of distance marketing in comparison with its closest competitors. These indicators provide an opportunity to analyze problem points in the company's communication activities in social media.

Accordingly, it is worth to evaluate the communication strategy to determine further areas for correction of communications. To do this, the following matrix tool is proposed, which makes it possible to determine which components in the communication strategy of the enterprise on the Internet would be appropriate to change (Table 4).

Table 4. Matrix of areas for correction of communication policy

\begin{tabular}{|c|c|c|c|}
\hline \multirow{4}{*}{ 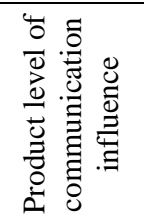 } & & \multicolumn{2}{|c|}{ Information level of communication influence } \\
\hline & & Appropriate & Inappropriate \\
\hline & Appropriate & Maintain existing communication & $\begin{array}{c}\text { Change the information level of } \\
\text { communication influence }\end{array}$ \\
\hline & Inappropriate & $\begin{array}{l}\text { Change the product contour of } \\
\text { influence }\end{array}$ & $\begin{array}{l}\text { Change both contours of } \\
\text { communication influence }\end{array}$ \\
\hline
\end{tabular}

The determination of the correspondence of each of the levels of communication influence shall be carried out by means of content analysis and expert evaluation methods, similar to the procedure for determination of the favourability of the communication environment described in this sub-paragraph.

Within the framework of the information society, the Internet network becomes not only a channel of information with the consumer, but also becomes an environment of functioning as manufactures, intermediaries and consumers. It opens up new opportunities for doing business to market entities. In these conditions, the model of communication in the network also changes. There is a different model on the Internet compared to traditional media, which involves the presence of many senders and many recipients of information (Dykha, M., Drobyazko, S., Hilorme, T., Oles, H. 2018, Polozova T.V. 2017).

Such changes in the environment require changes in the approaches and methods of managing marketing activities. In particular, it requires the transition from cyclic marketing management to a continuous process of management. In addition, in conditions where information becomes a key resource for both manufacturers and consumers, the issues of developing new effective communication methods in the hypermedia environment of the Internet are actualized.

Internet communications have their own peculiarities as opposed to traditional marketing communications. This specificity is due to a change in the models of communication in the network and the behavior of subjects on the Internet.

On the one hand, the information is influenced that is generated and circulated, and on the other hand, the user interacts with other users on the Internet. That is, a user in the process of interacting with others can become a member of a group, organization or network. In the conditions of the information society, the Internet becomes a host environment and user interactions in the form of communities, where their own information space is formed that affects the behavior of consumers.

That is, Internet-based marketing communications provide the opportunity to realize both short-term, which includes marketing and long-term (image) communication goals through a wide range of marketing tools that are inherent on the Internet environment but are rather effective along with traditional methods of promotion. The 
main task for an enterprise, when implementing communication activities on the Internet environment, is the formation of an integrated communication strategy in the network and the selection of optimal tools for its implementation.

Traditional approaches and methods for conducting marketing communication activities using enterprises in the conventional mass media are losing their effectiveness on the Internet. This is due to the fact that in the Internet space there is another model of dissemination of information, rather than in the usual media, as well as new types of communications that are inherent to the hypermedia environment, which necessitates the development of new methods and principles of management of communication activities of enterprises on the Internet.

Thereafter, improvement of existing methods of communication activities contributes to the development of social processes of interaction of subjects on the Internet environment. An Internet network from the information dissemination channel is transformed into an interaction environment of communication subjects, forming another information space that has an impact on consumer behavior. The proliferation of social networks and the formation of communities on the basis of Internet technologies are particularly contributing thereon. Such manifestation of social interaction can be used by the enterprise in the process of forming new approaches to communication activities on the Internet.

Advancement with the use of crowd technologies as well as the advancement of traditional communication tools are characterized by complexity in the evaluation of efficiency, due to the fact that all communications are implemented as short-term goals, mainly commercial and long-term goals, designed to build the image and manifest in the long-term period.

Thereafter, crowd technologies are characterized by the mechanism of self-reproduction of communications by users of the network, that is, at first the company promotes certain content on the network, and then the users themselves distribute it, hence the indicators of attraction become important (Polozova T., Beliavceva V., Perepeliukova O. 2018). The second important moment in the implementation of crowd technologies in marketing communications involves a non-linearity of the sales process; the potential customer does not always make a purchase as soon as he has received the information; often this purchase takes place with a delay in time, which complicates the assessment of the efficiency of the communication.

So, by analyzing the economic effect of using the methods of crowd marketing and other methods of promoting on the network, in particular, such as banner and context advertising, the means of crowd marketing are characterized by better economic indicators and, therefore, have a higher level of efficiency by reducing the cost of attracting one customer.

This is due to the peculiarities of the mechanism of the functioning of the crowd marketing, which consists in self-reproduction, that is, members of the communities themselves, on a royalty-free basis, transmit messages to each other, which reduces the total cost of impressions, and, as a consequence, the cost of switching to the site. Due to this, the final price of one order also decreases.

\section{Conclusion}

In accordance with the given matrix, the enterprise determines the further areas of correction of communications for each level of communication influence. If communication at both levels is appropriate, that is, the perception of the brand by consumers in line with the positioning strategy, you should support the chosen communication 
The International Journal

ENTREPRENEURSHIP AND SUSTAINABILITY ISSUES

ISSN 2345-0282 (online) http://jssidoi.org/jesi/

2018 Volume 6 Number 2 (December)

http://doi.org/10.9770/jesi.2018.6.2(36)

policy. If the context impact level is not appropriate to the company's advertising communications, the company can adjust this situation by spreading the desired context, refuting the wrong brand stereotypes among the communities. When the product information contour is inappropriate, this is due to the fact that consumers form a certain image of the product among community members, and the company emphasizes other brand benefits that consumers do not perceive. In this case, it is easier to change the advertising communication than to radically change the image of the brand. When the brand communication does not completely match its image among community members and among individual consumers, it is recommended to change both contours of communication influence. In order to apply the provisions of the concept of distance marketing in the communications activities of enterprises in the market, the scientific and methodological provisions of forming a communication strategy on the Internet have been improved, namely, the structural and logical scheme of formation of the marketing communication strategy on the Internet has been developed. Unlike existing schemes, this scheme is complemented by the stage of building a consumer interaction strategy on the Internet, which is the basis for identification of the consumer communications and networking communities on the Internet. The proposed stage is based on the analysis of the degree of readiness of target customers to purchase and the state of the communication environment of the enterprise.

So, the attraction of Internet technologies in the process of production and exchange between market players helps us to increase the level of efficiency of the enterprise and increase satisfaction of the needs of consumers. The use of Internet technologies provides the opportunity to form competitive advantages for manufacturers of products.

The research of scientific works has revealed that the complex of marketing communications on the Internet, besides traditional means, is also supplemented by specific communication means that are inherent only for the Internet environment, such as functioning of network communities, search optimization, lead generation, targeting, etc. Each of the elements of the Internet marketing communications complex is described and analyzed and the main task of the company's communication activities on the Internet is to develop a strategy of integrated marketing communications that optimally combines these tools to achieve the image and marketing goals of the enterprise.

The theoretical generalization of scientific works and empirical data showed that in the conditions of the development of the information society and the spread of Internet technologies, changes in consumer behavior patterns on the Internet environment are taking place. Accordingly, existing marketing principles of communication activity are losing their effectiveness, which has caused the need to improve the scientific and methodological provisions of marketing communication activities, taking into account the peculiarities of consumer behavior in the Internet space. In the course of the research, the peculiarities of consumer behavior on the Internet were identified, namely the ability to integrate into the networking community and their impact on marketing communications.

The study found that the use of the developed matrix method provides an opportunity to select the optimal strategy for interaction with the consumer on the Internet, based on the diagnosis of the state of the communication environment and the degree of readiness of the consumer to purchase. The developed strategies of interaction with the consumer on the Internet serve as the basis for the formation of a marketing communication strategy for enterprises of tablet computer manufacturers, which is reflected in the corresponding structural and logical scheme of forming the strategy of communication on the Internet. 


\section{References}

Cole, S. J. (2017). Use Value as a Cultural Strategy against Over-Commodification: A Durkheimian Analysis of Craft Consumption within Virtual Communities. Sociology, 52 (5), 1052-1068 https://doi.org/10.1177/0038038517726646

Dykha, M., Drobyazko, S., Hilorme, T., Oles, H. (2018). Innovative methods of performance evaluation of energy efficiency project. Academy of Strategic Management Journal, 17(2), 1-10. https://www.abacademies.org/articles/Innovative-methods-ofperformance-evaluation-of-energy-1939-6104-17-2-184.pdf

Hilorme, T., Nazarenko, I., Okulicz-Kozaryn, W., Getman, O. \& Drobyazko, S. (2018). Innovative model of economic behavior of agents in the sphere of energy conservation. Academy of Entrepreneurship Journal, 24(3) URL: https://www.abacademies.org/journals/monthseptember-year-2018-vol-24-issue-3-journal-aej-past-issue.html

Hilorme, T., Chorna, M., Karpenko L., Milyavskiy M. \& Drobyazko S. (2018). Innovative model of enterprises personnel incentives evaluation. Academy of Strategic Management Journal 17(3) URL: https://www.abacademies.org/journals/month-june-year-2018-vol-17issue-3-journal-asmj-past-issue.html

Homburg, C., Jozić, D., \& Kuehnl, C. (2017). Customer experience management: toward implementing an evolving marketing concept. Journal of the Academy of Marketing Science, 45(3), 377-401. https://doi.org/10.1007/s11747-015-0460-7

Jacobsen, L. F., Tudoran, A. A., \& Lähteenmäki, L. (2017). Consumers' motivation to interact in virtual food communities-The importance of self-presentation and learning. Food Quality and Preference, 62, 8-16.

Lou, L., \& Koh, J. (2017). Enhancing Fan Participation in Social Media Based Virtual Brand Communities: The Case of Like, Comment, and Share Activities. Asia Pacific Journal of Information Systems, 27(1), 54-76. https://doi.org/10.14329/apjis.2017.27.1.54

Markos, E., Labrecque, L. I., \& Milne, G. R. (2018). A New Information Lens: The Self-concept and Exchange Context as a Means to Understand Information Sensitivity of Anonymous and Personal Identifying Information. Journal of Interactive Marketing, 42, 46-62. https://doi.org/10.1016/j.intmar.2018.01.004

Polozova T., Beliavceva V., Perepeliukova O. 2018. Study on the state of international competitive positions of Ukraine. Financial and credit activity: problems of theory and practice, 3 (26), 236-244. URL: http://fkd.org.ua/article/view/144369/142825

Oghazi, P., Karlsson, S., Hellström, D., \& Hjort, K. (2018). Online purchase return policy leniency and purchase decision: Mediating role of consumer trust. Journal of Retailing and Consumer Services, 41, 190-200. https://doi.org/10.1016/j.jretconser.2017.12.007

Ponsford, R., Ford, J., Korjonen, H., Hughes, E., Keswani, A., Pliakas, T., \& Egan, M. (2017). Competing for space in an already crowded market: a mixed methods study of why an online community of practice $(\mathrm{CoP})$ for alcohol harm reduction failed to generate interest amongst the group of public health professionals at which it was aimed. Implementation Science, 12(1), 91. https://doi.org/10.1186/s13012$\underline{017-0622-8}$

Ringel, D. M., \& Skiera, B. (2018). Visualizing asymmetric competitive market structure in large markets: Methods and Applications in Marketing Management, Public Policy, and Litigation Support. In Handbook of Marketing Analytics. Edward Elgar Publishing.

Scheer, D., \& Rubik, F. (2017). Environmental governance and integrated product policy. In Governance of Integrated Product Policy (pp. 44-68). Routledge.

Wang, M., \& Qu, H. (2017). Review of the Research on the Impact of Online Shopping Return Policy on Consumer Behavior. Journal of Business Administration Research, 6(2), 15. https://doi.org/10.5430/jbar.v6n2p15

Polozova T.V. (2017). Development of methods for assessing the innovation and investment sensitivity of the enterprise. Financial and credit activity: problems of theory and practice, 1(22): 97-104. URL: http://fkd.org.ua/article/view/109933/105428

Nakashydze, L., \& Gil'orme, T. (2015). Energy security assessment when introducing renewable energy technologies. Eastern-European Journal of Enterprise Technologies, 4/8(76), 54-59. URL: http://nbuv.gov.ua/UJRN/Vejpte_2015_4\%288\%29_10 
The International Journal

ENTREPRENEURSHIP AND SUSTAINABILITY ISSUES

ISSN 2345-0282 (online) http://jssidoi.org/jesi/

2018 Volume 6 Number 2 (December)

http://doi.org/10.9770/jesi.2018.6.2(36)

Drobyazko, S. (2018). Personnel management as an element of the economic safety system of business // Competitiveness of entrepreneurial structures: features and prospects: Collective monograph. - Agenda Publishing House, Coventry, United Kingdom, 2018. 232 p., p. 192-197.

Kubeš, V., Rančák, J. (2018). Sustainability of organization performance via management techniques. Entrepreneurship and Sustainability Issues, 5(4), 1031-1042. https://doi.org/10.9770/jesi.2018.5.4(23)

Intekhab, A. (2018). How to Collaborate with Customers for New Service Development in Global Markets? Academy of Marketing Studies Journal, 22(3) URL: https://www.abacademies.org/articles/how-to-collaborate-with-customers-for-new-service-development-in-globalmarkets-7538.html

Illmeyer, M., Grosch, D., Kittler, M., Priess, P. (2017). The impact of financial management on innovation. Entrepreneurship and Sustainability Issues, 5(1), 58-71. https://doi.org/10.9770/jesi.2017.5.1(5)

Short biographical note about the contributors at the end of the article:

Oleksandra STOIAN Doctor of Public Administration, Head of Management Department, Associate Professor of Department, Petro Mohyla Black Sea National University, Ukraine

ORCID ID: orcid.org/0000-0002-3939-8816

Tetiana POLOZOVA, Doctor of Economic Sciences, Head of Department of Economic Cybernetics and Management of Economic Security, Kharkov National University of Radio Electronics, Ukraine

ORCID ID: orcid.org/0000-0001-9956-8816

Evgen DIDENKO, Ph.D in Economics, Associate Professor, Kharkov National University of Radio Electronics, Ukraine ORCID ID: orcid.org/0000-0002-5555-8429

Oleksandra STOROZHENKO, Candidate of Technical Sciences, Associate Professor, Kharkov National University of Radio Electronics ORCID ID: orcid.org/0000-0003-1674-9350

Olena MOSKVICHOVA, Ph.D in Economics, Associate Professor, Vinnytsia Financial and Economic University, Ukraine ORCID ID: orcid.org/0000-0002-0763-9929

Copyright (C) 2018 by author(s) and VsI Entrepreneurship and Sustainability Center

This work is licensed under the Creative Commons Attribution International License (CC BY).

http://creativecommons.org/licenses/by/4.0/

(c) (i) Open Access 